\title{
RELATIONSHIPS AMONG WORK LIFE, MENTAL HEALTH STATUS AND ORGANISATION-BASED SELF-ESTEEM
}

\author{
Hassan Fahim Devin ${ }^{1}{ }^{\#}$ and Davood Farbod ${ }^{2}$ \\ 1 Department of Physical Education and Sport Sciences, Mashhad Branch, Islamic Azad University, Mashhad, Iran; \\ h.fahimdevin@gmail.com \\ 2 Department of Mathematics, Quchan University of Advanced Technology, Quchan, Iran; d.farbod@ qiet.ac.ir \\ \# Corresponding author
}

Communicated by Isaak Rashal

\begin{abstract}
Quality of Work Life (QWL) is a multi-dimensional concept that covers employees' feelings about various dimensions of work. The current study focused on QWL that can contribute to the mental health status and Organisation-Based Self-Esteem (OBSE) of employees in context of sport organisation in Iran. In this descriptive-correlative study, data was collected using three standard questionnaires: Goldberg's (1978) General Health Questionnaire (GHQ-12), Pierce, Gardner, Cummings and Dunham's (1989) OBSE scale, and Walton's (1975) QWL questionnaire. The statistical sample of the study consisted of 67 (53 male, 14 female) employees of sport and youth organisations of the Northern Khorasan Province of Iran. The alpha value for mental health, OBSE and QWL questionnaires were, respectively, 0.82, 0.80, 0.79. QWL was significantly correlated with mental health status and self-esteem of employees. Thus, it can be concluded that mental health and self-esteem of employees depend on how these employees perceive QWL in organisations. Among QWL subscales, fair and adequate pay along with growth opportunities were the strongest predictors of mental health; growth opportunities along with development of human capabilities were the strongest predictors of self-esteem of employees. Our study adds to the growing body of research on mental health status in relation to factors such as QWL. In view of our findings, we hope that improving work environment as a means of improving one's mental health status will be more emphasized by organisation managers.
\end{abstract}

Key words: Quality of Work Life, mental health status, Organisation-Based Self-Esteem.

\section{INTRODUCTION}

The term Quality of Work Life (QWL) gained importance in the late 1960s as concerns developed about the effect of job/work on health and general wellbeing and ways to positively influence the quality of a person's work experience.

Up until the mid-1970s, employers emphasised improvement of work design and working conditions. In the next decade (1980s), the concept of QWL included other aspects of a job that affect employees' job satisfaction and productivity, such as reward system, physical work environment, employee involvement, rights and esteem needs.

Robbins defined QWL as a process by which an organisation responds to employees' needs by developing mechanisms to allow them to share fully in making the decisions that design their lives at work (Robbins, 1989, at p. 207). A complete historical overview of QWL was previously prepared (Martel and Dupuis, 2006).

Mental health is a state of emotional and psychological well-being in which an individual is able to use his or her cognitive and emotional capabilities, function in society, and meet the ordinary demands of everyday life (Anonymous, 2016).

Good mental health is crucial to the overall well-being of individuals, communities, and societies. Positive mental health is a resource of everyday living that enables people and communities to realise their fullest potential and to cope with life transitions and major life events.

Researchers have distinguished among several types of esteem, including global self-esteem (an individual's overall evaluation of worth), role-based self-esteem (worth derived from employment in a particular position), and task based self-esteem (worth based on self-efficacy). Within the last five years, an additional form, Organisation-Based SelfEsteem (OBSE), has appeared in the literature. OBSE reflects the degree to which employees perceive themselves as important, meaningful, effectual, and worthwhile within the organisational setting (Pierce et al., 1989).

A high-quality working life can be defined as one that involves an interesting, challenging, and responsible job. 
Woolf (2004) pointed out that a high QWL would reward the worker with a just wage for his work and recognition of other kinds for contribution, such as promotion to a better paid, more responsible position, more secure job, more opportunities to grow and as far as the work place allows, and better lit, cleaner, quiet, safer, and more spacious work place. Thus, QWL is a comprehensive construct that includes an individual's job-related wellbeing and the extent to which work experience is rewarding, fulfilling and devoid of stress, psychological disorders (better mental health) and other negative personal consequences. According to the World Health Organisation (Anonymous, 2001), "mental health problems and stress-related disorders are the biggest overall cause of early death in Europe". Some of the root causes of this morbidity and mortality are related to living and working conditions that are accessible to preventive and therapeutic interventions, individuals as well as collective ones. According to the results of a study by Markham (2010), "The prediction of employees, mental health by means of their QWL" it was evident that QWL variables and more specifically lack of meaningfulness, are predictors of employees' mental health; and work and time pressure, skill discretion and role ambiguity are predictors of employees' general health, somatic symptoms and anxiety.

Self-esteem is a basic human need and for which we constantly strive. QWL is so vast a concept that it encompasses the whole chain of a person's various needs. QWL was conceptualised in terms of need satisfaction stemming from an interaction of workers' needs (survival, security, social, self-esteem, and self-actualisation) and organisational resources (Sirgy et al., 2001).

As Rhoades and Eiesenberger (2002) stated, nowadays people not only work for physiological need, but also and most importantly work for non-material needs such as selfesteem and self-actualisation needs in the form of growth and achieving career goals. The results suggest that QWL should be taken into account in order to improve mental health status and self-esteem of employees.

On numerous occasions it has been suggested that an individual's self-esteem, formed around work and organisational experiences, plays a significant role in determining employee motivation, work-related attitudes, and behaviours. We review more than a decade of research on an organisation-based conceptualisation of self-esteem. It is observed that sources of organisational structure, working environment structure, signals about worth from the organisation, as well as, success-building role conditions predict organisation-based self-esteem. In addition, OBSE is related to job satisfaction, organisational commitment, motivation, citizenship behaviour, in-role performance, and turnover intentions, as well as, other important organisation-related attitudes and behaviours (Pierce and Gardner, 2004).

The aim of this study was to analyse how mental health and self-esteem of employees may be influenced by QWL. This study also tries to predict the mental health status and OBSE of employees through QWL subscales.
The following hypotheses were raised: 1) there is a correlation between QWL and mental health status of employees, 2) there is a correlation between QWL and OBSE of employees, and 3) the subscales of QWL can predict the mental health and self-esteem of employees.

\section{METHODS}

In this descriptive study, relationships were determined among parameters assessed by three standard questionnaires using correlation and other statistical analyses to test the hypothesis.

All statistical computations were conducted using SPSS software version 17 . Sixty seven (53 male, 14 female) employees of sport and youth organisations of the Northern Khorasan Province were selected as a statistical sample and responded to three standard questionnaires.

Mental health status of participants in this study was measured using Goldberg (1978) GHQ (GHQ-12) 12 items, a self-administered scale that yields the current experience of a symptom and behaviour specific to psychological distress, on a four point (0-3) Likert scale with a total score of 36. It mainly focuses on the two major areas, 1) the inability to carry out normal functions, and 2) the appearance of new and distressing phenomena. A score of more than 20 on GHO-12 indicates severe psychological problems and distress.

Perspective of employees on self-esteem was measured using the OBSE scale developed by Pierce et al. (1989). The scale consists of ten items on two factors, organisation-based self-respect was composed of six items and organisation-based self-confidence contains four items and was measured on a 6-point scale ranging from strongly disagree (1) to strongly agree (6).

Walton's (1975) 44 items questionnaire with eight subscales on a five-point scaled response ranging from strongly disagree (1) to strongly agree (5) was used to measure the status of QWL in the mentioned organisation.

Data was obtained during two different time periods during the participant working times. The questionnaires were administered and the participants were asked to choose the cases among Likert-scale (Norman, 2010) items that were true to them.

The Pearson's coefficient correlation test was used to test the hypothesised relationships between the variables. Furthermore, multiple step by step regression analysis (see, for example, Bhattacharyya and Johnson, 1977) was performed to predict the strongest predictors of employees' mental health and self-esteem among QWL subscales.

Compared to Fahim et al. (2014), the coefficient alpha was used to test the reliability of the instruments. Although the instruments were proven to be reliable, reliability testes were needed for this study, since the instruments had been 
translated into the language Farsi, and were used in a different culture at a different period of time since the original study. An internal consistency estimate was computed for three instruments and the alpha value for mental health, OBSE and QWL were respectively, 0.82, 0.80, and 0.79.

\section{RESULTS}

Descriptive statistics. Table 1 displays the means (M) and standard deviations (SD) of variables from the perspective of participants. According to mean scores of variables, employees who participated in this study were at a moderate level in mental health status $(X=19.05$, from a maximum score of 36 . A a score of more than 20 indicates severe psychological problems and distress.

Table 1

DESCRIPTIVE STATISTICS OF VARIABLES

\begin{tabular}{c|c|c|c|c|c}
\hline Variable & N & M & SD & $\begin{array}{c}\text { Minimum } \\
\text { possible }\end{array}$ & $\begin{array}{c}\text { Maximum } \\
\text { possible }\end{array}$ \\
\hline Mental health & 67 & 19.05 & 9.11 & 0 & 36 \\
OBSE & 67 & 31 & 5.80 & 1 & 60 \\
QWL & 67 & 2.28 & 0.97 & 1 & 5
\end{tabular}

QWL, Quality of Work Life; OBSE, Organisation-Based Self-Esteem; SD, Standard Deviation

The mean estimated OBSE was ( $\mathrm{X}=31$, maximum possible 60). This implies that employees waver between feeling able and useless, right and wrong, acting at times wisely and rashly at others. The QWL mean score was lower than average ( $X=2.28$ of maximum 5$)$. In this study, most of the employees felt dissatisfied with the scope of work, fair and adequate pay, pressing work environment, and promotional opportunities.
Table 2

CORRELATION BETWEEN VARIABLES (QWL WITH MENTAL HEALTH AND OBSE)

\begin{tabular}{l|c|c|c|c}
\hline \multicolumn{1}{c|}{ Variables } & $\mathrm{N}$ & Correlation $(\mathrm{r})$ & $p$ & $\mathrm{r}^{2}$ \\
\hline QWL and Mental Health & 65 & -0.446 & 0.004 & 0.199 \\
QWL and OBSE & 65 & 0.398 & 0.023 & 0.158
\end{tabular}

For abbreviations see Table 1

Results of correlation analysis. Table 2 shows the results of testing the first and second hypotheses of the study. There was a negative significant correlation between QWL with mental health. This implies that a better quality of working life is associated with less work-related stress for employees and as a result with less psychological disorders (or better mental health). There was also a significant correlation between QWL with OBSE. This implies that good working conditions (physical, social, and psychological characteristics of work settings) lead to a sense of satisfaction and achievement and can boost employee self-esteem and personal identity.

Results of multiple regression analysis. Step-wise multiple regression analysis was conducted to determine the predictors of mental health status (hypothesis 3). The results presented in Table 3 show that fair and adequate pay and growth opportunities and continuing security were the best predictors of mental health. Fair and adequate pay (Beta $=$ $0.432, \mathrm{~T}=3.621, p<0.05$ ) was the strongest predictor of mental health, followed by growth opportunities and continuing security (Beta $=0.283, \mathrm{~T}=2.440, p<0.05$ ) as the second strongest predictor of mental health. Predictors of OBSE from QWL subscales (Table 4) were development of human capabilities and growth opportunities were the strongest predictors of OBSE. Development of human capabilities (Beta $=0.47, \mathrm{~T}=6.51, p<0.05$ ) was the strongest predic-

COEFFICIENT FOR PREDICTORS OF QWL FOR MENTAL HEALTH

\begin{tabular}{|c|c|c|c|c|c|}
\hline \multirow[t]{2}{*}{ Model } & \multicolumn{2}{|c|}{ Unstandardised Coefficient } & \multirow{2}{*}{$\begin{array}{c}\text { Standardised Coefficient } \\
\text { Beta } \\
\end{array}$} & \multirow[t]{2}{*}{$\mathrm{T}$} & \multirow[t]{2}{*}{$p$} \\
\hline & SE & $\mathrm{B}$ & & & \\
\hline Constant & 6.162 & 0.969 & & 4.067 & 0.001 \\
\hline Fair and adequate pay & 0.037 & 6.426 & 0.432 & 3.621 & 0.003 \\
\hline Growth opportunities and continuing security & 0.689 & 6.217 & 0.283 & 2.440 & 0.018 \\
\hline
\end{tabular}

Dependent variable: mental health. QWL, Quality of Work Life; SE, Standard Error

COEFFICIENTS FOR PREDICTORS OF QWL FOR OBSE

\begin{tabular}{|c|c|c|c|c|c|}
\hline \multirow[t]{2}{*}{ Model } & \multicolumn{2}{|c|}{ Unstandardised Coefficient } & \multirow{2}{*}{$\begin{array}{c}\text { Standardised Coefficient } \\
\text { Beta }\end{array}$} & \multirow[t]{2}{*}{$\mathrm{T}$} & \multirow[t]{2}{*}{$p$} \\
\hline & SE & $\mathrm{B}$ & & & \\
\hline Constant & 0.493 & 1.059 & & 2.149 & 0.036 \\
\hline Growth opportunities and continuing security & 1.12 & 0.46 & 0.31 & 3.79 & 0.001 \\
\hline
\end{tabular}

For abbreviations see Table 1. Dependent variable: OBSE. 
tor of OBSE, followed by growth opportunities (Beta=0.31, $\mathrm{T}=3.79, p<0.05$ ).

\section{DISCUSSION}

There was a significant correlation between QWL and mental health status (negative correlation) and self-esteem of employees (Hypothesis 1 and 2). Thus, it can be concluded that mental health and self-esteem of employees depend on how these employees perceive QWL in organisations. If employees feel that the organisation provides them growth opportunities and continuing security with a safe and healthy work place, and also provide them with fair and appropriate compensation, they feel that the organisation can fulfil their personal needs. Since the average adult spends much of his or her life working, the work place can play a significant part in an individual's life that can affect his or her life and psychological well-being. When individuals have good mental health, they are able to function properly (Ryff, 1989). The obtained results are consistent with those of Siegrist et al. (2006) and Zulkarnain (2013). In their study they found that components of QWL, such as work environment, wages, work schedules and growth opportunities are closely associated with life satisfaction, well-being and self-esteem of workers, which is in line with the findings of this study. Sirgy et al. (2001) also reported that QWL does not only affect job satisfaction, but it will also affects life satisfaction, such as family life, social life, financial and well-being of workers.

Self-esteem is the basic appraisal of oneself, as it concerns the overall value that one places on oneself, as a person (Rosenberg, 1965). Based on Korman (1970, 1976), the way individuals react to life experiences is, among others, based on the extent to which they perceive themselves as being able to satisfy their needs. The basic underlying theoretical tenet is that individuals will develop attitudes and behave in a way that will maintain their level of self-esteem. The reasons behind this are that QWL is more focused on staff development and improving the well-being of workers in order to improve performance of an organisation (Cole et al., 2005). QWL involves designing a comfortable work full of joy to enhance the psychological environment, which can improve employee performance and responsibilities, while increasing individual internal motivation to work in earnest. The results suggest that QWL should be taken into account in order to improve mental health status and self-esteem of employees.

This study confirmed the importance of QWL for mental health and self-esteem in many respects. It showed that employees' perception of their work place tended to shape their psychological well-being and their feeling of self-respect and self-confidence. It can be concluded that employee well-being and OBSE play critical roles in the motivation of human behaviour. Organisational policies, programmes and procedures and quality of working conditions that lead to the promotion of psychological well-being of employees and development of their self-esteem in a healthy way will be very useful both for the organisation and the individual.

Managers must have the mission to improve their employee mental health and self-esteem in order to contribute to the achievement of organisational goals and as well as the personal goals of the members.

\section{CONCLUSION}

Employee mental health can be developed by organisations through fair and adequate pay and growth opportunities (these two components of QWL were the strongest predictors of mental health), and sense of self-esteem can be developed by organisations through a safe and healthy work place and development of human capabilities (these two components of QWL were the strongest predictors of OBSE).

From an organisational psychological perspective (Danna and Griffin, 1999), QWL involves a hierarchy of concepts that include life satisfaction, job satisfaction, and work-specific facet satisfaction. Since the average adult spends much of his or her life working, the work place becomes a significant part of his or her life that affects the life and well-being of an individual. When individuals have a good psychological well-being and experience positive emotions like happiness in work place, they are able to function properly (Ryff, 1989). Individuals are also able maintain confidence and have a great sense of self-esteem and generally become a better person in life. It can also be concluded that OBSE plays a critical role in the motivation of human beings.

Limitations and suggestions for future research. Sample size was the major limitation of the study. Sixty seven employees participated in this study. The sample size could be larger in order to provide more powerful results. Another limitation was the exclusive use of self-report measures, a strategy often associated with method variance. The outcome of the study depended on the participants' honesty and cooperation in answering the questions.

From a researcher's perspective, future research should consider also physical activity and sport engagement level of employees, as well as emotional Intelligence as mediating variables, because these variables may have important roles in fostering mental health and self-esteem of employees and can be linked with QWL.

\section{ACKNOWLEDGMENTS}

The authors are thankful to the Editor-in-Chief, Managing Editor and two anonymous referees for their highly constructive suggestions that led to a great improvement to the expression of this paper.

\section{REFERENCES}

Anonymous (2001). Mental Health in Europe. WHO Regional Office for Europe, Copenhagen. 
Anonymous (2016). Mental health. American Heritage Dictionary. See: https://ahdictionary.com/word/search.html?q=mental+health

Bhattacharyya, G. K., Johnson, R. A. (1977). Statistical Concepts and Methods. Wiley. $656 \mathrm{pp}$.

Cole, D. C., Robson, L. S., Lemieux, ChMcguire W, Sicotte W, Champagn F. . (2005). Quality of working life indicators in Canadian health care organizations: A tool for healthy, health care work place? Occup. Med., 55, 54-59.

Danna, K., Griffin, R. W. (1999). Health and well being in the work place: A review and synthesis of the literature. J. Manag., 25 (3), 357-384.

Fahim Devin, H., Arji, M., Farbod, D. (2014). Investigating the relationship between organizational justice and employees mental health status. Bull. Georgian Nat. Acad. Sci., 8 (2), 116-122.

Goldberg, D. (1978). Manual of the General Health Questionnaire. Windsor: NFER, Nelson.

Korman, A. K. (1970). Toward a hypothesis of work behaviour. J. Appl. Psychol., 54, 31-41.

Korman, A. K. (1976). Hypothesis of work behavior revisited and an extension. Acad. Manag. Rev., 1, 50-63.

Markham, L. G. (2010). Quality of Work Life as Predictor of Employees' Mental Health. University of the Free State Bloemfontein, p. 200. Available at:

http://citeseerx.ist.psu.edu/viewdoc/download?doi=10.1.1.475.6713\& rep=rep $1 \&$ type $=$ pdf

Martel, J. P., Dupuis G. (2006). Quality of work life: Theoretical and methodological problems, and presentation of new model and measuring instrument. Soc. Indicator Res., 77, 333-368.

Norman, G. (2010). Likert scales, levels of measurement and the laws of statistics. Adv. Health Sci. Educ., 15 (5), 625-632.
Pierce, J. L., Gardner, D. G., Cummings, L. L., Randall, B. D. (1989). Organizational based self-esteem: Construct, Definition, Measurement and Validation. Acad. Manag. J., 36, 211-288.

Pierce, J. L, Gardner, D. G. (2004). Self-esteem within the work and organization context. J. Manag., 30 (5), 591-622.

Rhoades, L., Eisenberger, R. (2002). Perceived organizational support: A review of literature, J. Appl. Psychol., 87, 698-714.

Robbins, S. P. (1989). Organizational Behavior: Concepts, Controversies and Applications. Prentice-Hall, Englewood Cliffs, NJ.

Rosenberg, M. (1965). Society and the Adolescent Self-image. Princeton, NJ: Princeton University Press.

Ryff, C. D. (1989). Happiness is everything, or is it? Explorations on the meaning of psychological well-being. J. Person. Soc. Psychol., 57 (6), 1069-1081.

Siegrist, J., Wabrendorf, M., Supan, A. (2006). Quality of work, well-being and intended early retirement of older employees base line results from the SHARE study. Eur. J. Publ. Health, 17 (1), 62-68.

Sirgy, J. M., Efraty, D., Siegel, P., Lee, D. (2001). A new measure of QWL based on need satisfaction and spillover theories. Soc. Ind. Res., 3, 241-302.

Walton, R. E. (1975). Criteria for Quality of Working Life. In: Davis, L. E., Chers, A. B. (eds.). The Quality of Working Life. The Free Press, New York, NY, pp. 91-104.

Woolf, B. (2004). 8 ways to improve quality of life at work: Learn to separate who you are from your job. Available at: http://www.c4ql.com/images/BWarticlecareerbuilder.pdf

Zulkarnian, A. (2013). The mediating effect of QWL on the relationship between career development and psychological well-being. Int. J. Res. Studies Psychol., 2 (3), 67-70.

Received 28 February 2016

\section{ATTIECĪBA STARP DARBMŪŽU, GARĪGO VESELĪBU UN AR DARBA VIETU SAISTĪTO PAŠNOVĒRTĒJUMU}

Darbmūža kvalitāte ir koncepcija, kas ietver darbinieka izjūtas par dažādiem darba apstākḷiem. Pētījums balstīts uz Irānas sporta organizācijas darbinieku aptaujām. Secināts, ka darbinieku garīgā veselība un pašnovērtējums ir saistīts ar to, kā viṇi uztver darbmūža kvalitāti organizācijā. Šajā ziṇā svarīgākie elementi ir godīga un adekvāta alga un izaugsmes iespējas. 